\title{
Effect of Growth Rate on Wood Specific Gravity of Three Alternative Timber Species in Sri Lanka; Swietenia macrophylla, Khaya senegalensis and Paulownia fortunei
}

\author{
P.K.P. Perera* ${ }^{1}$, H.S. Amarasekera ${ }^{1}$, N.D.R. Weerawardena ${ }^{2}$ \\ ${ }^{1}$ Department of Forestry and Environmental Sciences, University of Sri Jayewardenepura \\ ${ }^{2}$ Forest Research Center, Kumbalpola, Sri Lanka Forest Department
}

Date Received: 28-11-2011～Date Accepted: 29-03-2012

\begin{abstract}
With increasing private sector investments in commercial forestry, it is apparent that plantation forestry in Sri Lanka is moving in the direction of managing fast growing timber species for shorter rotations. However, there's a perceptionthat accelerated growth rates induced by improved forest management practices can result in inferior wood quality. This study tested this perceptionby studying the effect of growth rate on the specific gravity, as a proxy for wood quality, of three alternative timber species grown in Sri Lanka; Swietenia macrophylla, Khaya senegalensis and Paulownia fortunei. Specific gravity remained more or less uniform from pith to bark regardless of the fluctuation of ring width in $K$. senegalensis while $S$. macrophylla exhibited a slight increase in specific gravity from pith to bark. This increasing trend was more prominent in $P$. fortunei. Results revealed growth rates represented by ring width showed poor correlations with specific gravity in both $S$. macrophylla, and $K$. senegalensis. Although $P$. fortunei showed a statistically significant positive correlation, regression analysis indicated a poor relationship between growth rate and specific gravity. Hence it is unlikely that wood specific gravity of the studied species to be influenced by accelerated growth rates.
\end{abstract}

Key words: Growth rate, specific gravity, ring width, wood quality, Swietenia macrophylla, Khaya senegalensis, Paulownia fortunei

\section{Introduction}

Forest plantations in Sri Lanka have steadily increased over the last few decades as the pressure to conserve existing natural forests has increased. Numerous reports suggest that the booming economy coupled with expanding population is likely to drive the demand for sawn wood even higher (Forest Sector Master Plan, 1995; Perera et al., 2006). Recognizing the importance of forest plantations in meeting the country's demand for sawn timber, the government has made provisions such as long-term land leases under concessionary rates for forestry projects to encourage private sector participation in forestry (Ministry of Environment and Natural Resources Sri Lanka, 2002). Meanwhile, investments in commercial forest plantations are also on the rise (CBSL, 2004). As such, the upward trend in expansion of forest plantations is also likely to continue.

*Correspondence: priyan@sjp.ac.lk

Tel:+94-112758411, Fax: +94 112803470

ISSN 2235-9370 Print / ISSN 2235-9362 Online C2012 University of Sri Jayewardenepura 
At present, Sri Lanka's forest plantations are dominated by fast growing exotic timber species such as Eucalyptus spp, Pines (Pinus caribaea and P. patula), Teak (Tectona grandis), and Mahogany (S. macrophylla). In addition to these well-known timber species, both state (Forest Department) and private sector plantation companies have increasingly become interested in introducing new, commercially valuable, fast growing timber species. Among these, K. senegalensis, also known as African mahogany is of special interest. $K$. senegalensis has been introduced to the country more than 45 years ago as a shade and amenity tree. However, large scale plantation establishment with Khaya for timber purposes was initiated about 15 years ago by the Forest Department. $K$. senegalensis is predominantly grown in dry and intermediate climatic zones of the country. Paulownia fortuneion the other hand is not yet grown by the Forest Department in large scale, but the private sector is showing interest in this species, possibly due to its fast growth rates and multiple uses (Jørgensen and Vivekanandan, 2003).

However, a major drawback for the promotion, management and efficient utilization of new timber species such as $K$. senegalensis and $P$. fortuneiis the lack of information regarding their wood properties and wood quality when grown under localconditions in Sri Lanka. Availability of such information prior to large scale forest plantation establishment plays a crucial role in selecting the species most appropriate for the envisaged end use. Even for popular timber species such as $S$. macrophylla, wood property information when grown under local conditions is rare in the literature (Amarasekera, 1996).

With increasing private sector investments in commercial forestry, it is apparent that plantation forestry in Sri Lanka is moving in the direction of managing fast growing timber species for shorter rotations. However, Larson (1972) proposed that accelerated growth rates induced by improved forest management practices may result in wood of inferior quality. Larson's argument has been well supported by numerous studies (Bhat and Bhat, 1983; Herman et al., 1998; Simatupang et al., 2000). Therefore, understanding the effect of growth rate on wood quality is highly important so that forester managers can effectively manipulate tree growth to yield better quality timber. In the context of the three timber species examined in this study, i.e. S. macrophylla, K. senegalensis and P. fortunei, no previous information exists in literature on effects of growth rate on wood quality, especially when grown under local conditions. Hence, this study attempts to bridge the information gap by investigating the radial variations of specific gravity with growth rate as measured by ring width.

\section{Literature Review}

Wood properties vary greatly within a tree. Wood property variation patterns that arise from apical or cambial aging and positional effects of the crown are regarded as intrinsic. External factors such as environment, site conditions and silvicultural treatments also have impacts on regular patterns of wood variation and these are regarded as extrinsic. Wood properties vary within the position in a tree and with the age at which the growth sheath is formed. Therefore, systematic radial and axial patterns of wood property variations can be identified (Amarasekera and Denne, 2002).

Specific gravity may be the most widely studied property of wood. Specific gravity is a function of the proportion of cell wall materials versus cellular voids. Many authors identify specific gravity as a key wood property in forest products because it has a major effect on the yield and quality of both fibrous and solid wood products (Bhat, 1985; Haslett and Young, 1990). As such, specific gravity is often considered as a measure of with wood quality (Zobel and van Buitjenen, 1989; Woodcock and Shier, 2002). Numerous authors have classified timber species based on specific gravity as it is the single best index that can be easily measured to predict strength properties of wood (Bhat, 1985; Amarasekera, 1996). 
The literature contains significant body of research that examines radial variation in wood specific gravity within hardwood trees (Lei et al., 1997; Bao et al., 2001; Woodcock and Shier, 2002; Amarasekera and Denne, 2002; Ruwanpathirana, 2002; Nock et al., 2009; Lin et al., 2012). Such studies in general cite the existence of juvenile wood and mature wood as the main cause of radial trends in wood specific gravity. For instance, Bao et al. (2001) observed considerable differences in most wood properties (including specific gravity) between plantation-grown juvenile wood and mature wood, and between naturally-grown juvenile wood and mature wood. Based on their findings, Bao et al. (2001) argued that "wood properties of plantation-grown trees greatly depends on juvenile wood content, and can thus be manipulated effectively through varying rotation age". Generally, the longer the rotation age, the lower the juvenile wood content and superior the wood properties. Apart from genetic factors, higher growth rates are often resulting from improved site, nutrient and environmental conditions and intense silvicultural control. There are no certain patterns that hold regarding the relationship between growth rate and wood quality or specific gravity, and literature can be found to support nearly any chosen point of view. The relationship depends on the species and the site concerned as well as on how the growth is expressed (Zobel and van Buitjenen, 1989).

Several works based on softwoods emphasize the detrimental effect of growth rate on specific gravity (Schmidtling and Amburg, 1977; Pearson and Gilmore, 1980; Zhang, 1995; Ruwanpathirana, 2002) although examples are available in the review of Zobel and van Buitjenen, (1989) to illustrate different trends. Herman et al. (1998) observed that increasing the growth rate in circumference of Norway spruce from 1.7 to $2.7 \mathrm{~cm} /$ year by heavy thinning induced a limited decrease in wood density. However, he concluded that the decrease in wood density is so minorthat stand productivity can be improved without significantloss of wood quality.

Diffuse porous and ring porous hardwoods are affected differently by growth rate. Generally, growth rate differences have little effect on specific gravity of diffuse porous hardwoods with few exceptions (MacDonald and Franklin, 1969; Ruwanpathirana, 2002). For instance, Ruwanpathirana (2002) observed that in fast growing sites of Eucalyptus grandis, the specific gravity increased from pith and thereafter remained constant towards the bark with small fluctuations. Specific gravity increased gradually towards bark in slow and medium growth sites. Fast growing sites maintain the highest specific gravity from pith to bark. According to Briscoe et al. (1963), the specific gravity of $S$. macrophylla tends to increase with growth rate. Zhang (1995) observed growth rate to generally have very little influence on specific gravity of diffuse porous hardwoods.

Wood density decreases under fast growth rates in certain diffuse porous hardwoods. According to Haslett et al. (1991), wood of plantation crops grown on rotations of 10 to 20 years can be of significantly lower density. For example, 14 year old plantation grown Eucalyptus deglupta is shown to have $30 \%$ lower density than values for the same species grown in Papua New Guinea. According to Zhang (1995), specific gravity does not remarkably decrease with growth rate in ring porous hardwoods, while some species tend to show an increase in specific gravity with increasing growth rates. Simatupang et al. (2000) report that $S$. macrophylla wood from short rotation plantations is of inferior quality to that of matured naturally grown timber.Conversely, many studies indicate no significant relationship between tree size representing growth rates and specific gravity of $S$. macrophylla (Chudnoff and Geary, 1973; Lin et al., 2012).Studies to explain the radial variation of specific gravity with growth rate of $K$. senegalensis and $P$. fortunei are rare in literature.

Higher timber yields and uniform wood from shorter rotations are key incentives for developing intensively managed timber plantations (Pérez and Kanninen, 2005). In the context of the three study species, no adequate data are available in literature to explain the effect of growth rate on wood quality, especially when grown under Sri Lankan conditions. Wood property variations with growth rates in $K$. senegalensis and $P$. fortune in general have received scant scholarly attention in both international and 
local literature. Therefore, the primary objective of this study was to investigate the effect of growth rate on radial variations of specific gravity in species $S$. macrophylla, K. senegalensis and $P$. fortunei.

\section{Materials and Methods}

Three sites where $S$. macrophylla, $K$. senegalensis and $P$. fortunei are growing were selected to obtain test specimens. All sites were from the intermediate climatic zone of the country. S. macrophylla were obtained from 79 year-old Jak-Mahogany plantation in Kurunegala. K. senegalensis specimens were obtained from a 49 year-old plantation in Kankaniamulla while $P$. fortunei were from a16 year-old plantation in Agaratenna, Badulla. Fifty trees from each sampling plot were randomly selected and classified into "dominant", "co-dominant" and "suppressed" based on their DBH. Three trees with straight and non-leaningboles from each species belonging to the co-dominant size class were randomly selected and felled. Each tree (and sample disk) was named as indicated in Table 1 for the ease of reference. Sample disks of 2 inch thickness were extracted from each tree at breast height.

Table 1: Age, mean DBH and mean height of selected trees

\begin{tabular}{lcccccc}
\hline & & & & Age & \multicolumn{2}{c}{ Mean } \\
\cline { 5 - 7 } Species & Tree 1 & Tree 2 & Tree 3 & (years) & DBH (cm) & Height (m) \\
\hline S. macrophylla & M1 & M2 & M3 & 79 & 36.0 & 18 \\
K. senegalensis & K1 & K2 & K3 & 49 & 41.8 & 20 \\
$P$. fortunei & P1 & P2 & P3 & 16 & 22.6 & 10 \\
\hline
\end{tabular}

Each sample disk was planed and sanded to better observe the growth rings. The growth rings were visually identified with the aid of a hand lens. Rings were marked along a linear section that goes across the pith, avoiding reaction wood areas. False rings were ignored. Ring width was measured using a travelling microscope to an accuracy of $0.01 \mathrm{~cm}$. Rings were identified and markedto both directions from the pithand the mean value was taken as the ring width of the corresponding ring. The maximum moisture content method proposed by Smith (1954) was used to determine the specific gravity of wood. Four match-stick sized specimens were extracted from each ring ( 2 from the left and 2 from the right to the pith) and mean value was taken as the specific gravity corresponding to each ring (Figure 1). Data were analyzed using Minitab 16 statistical software.

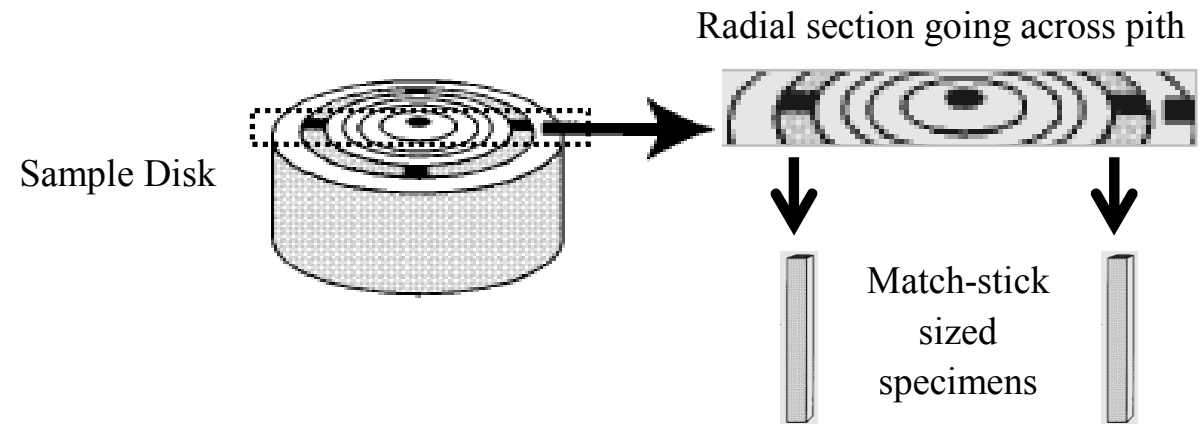

Figure 1: Diagram of sample preparation from a disk extracted at breast height

\section{Results}

In this study, ring width was the parameter selected to represent growth rate. Variations of ring width from pith to bark for the three studied species at breast height level are illustrated in Figure 1. In general, ring width showed a gradual increase after first few growth rings in all the studied species. In both $S$. macrophylla and $K$. senegalensis, wider growth rings were observed for sheaths corresponding to the period of 3 to 20 years in the tree life history. After that, growth increments gradually declined for 
both species and remained more or less constant. In $P$. fortunei, wider growth rings were visible for sheaths corresponding to the period of 3 to 10 years in tree life history. The sharp increase in ring width in $P$. fortuneiwas followed by a gradual decline towards the bark.For each species, between-tree variations in ring width/growth rate were less prominent.
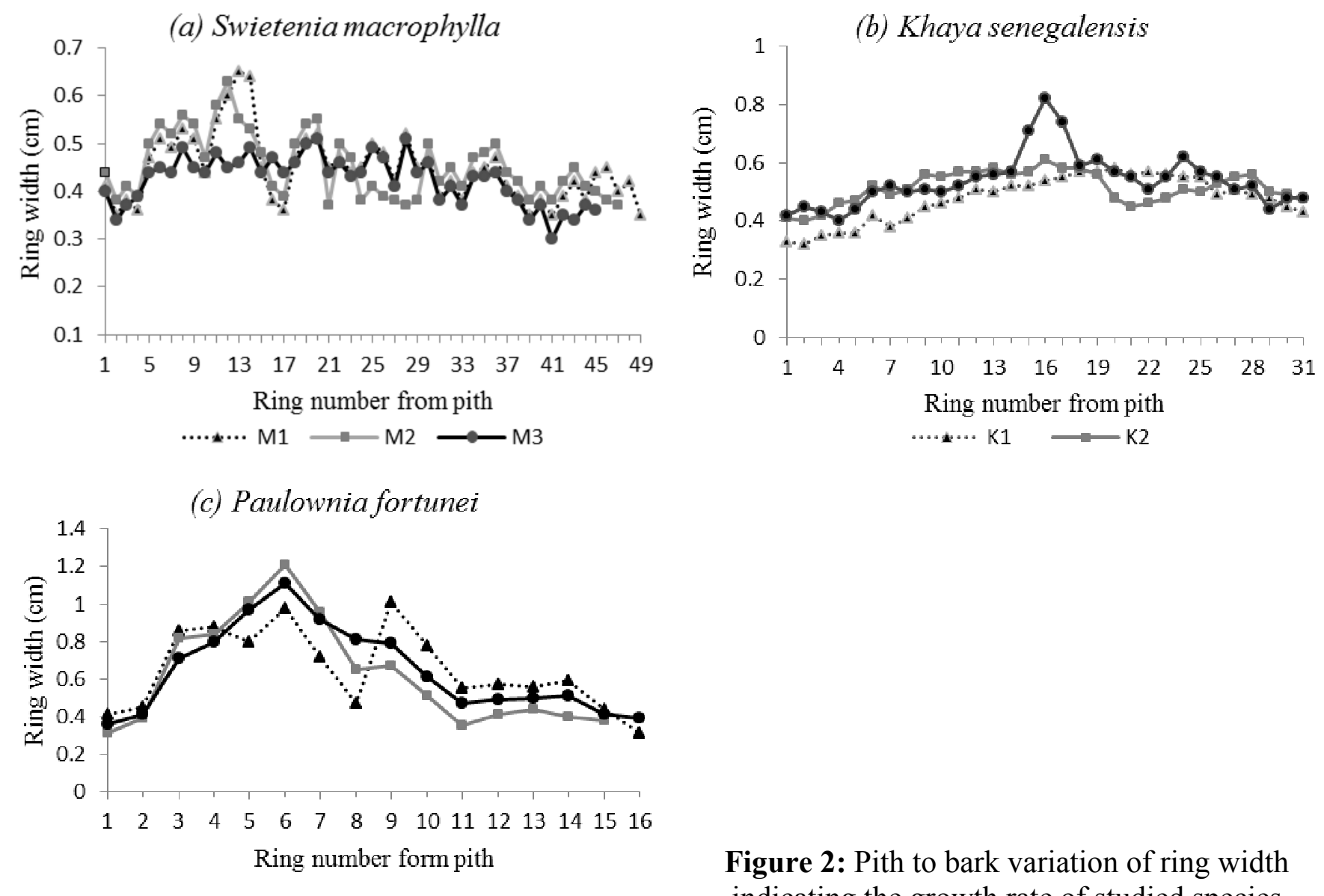

Figure 2: Pith to bark variation of ring width indicating the growth rate of studied species

Since specific gravityis associated withwood quality, specific gravity was determined for each growth ring in the sample disks forthe three species. The highest mean specific gravity at breast height was recorded for $K$. senegalensis $(0.614)$ followed by $S$. macrophylla $(0.514)$ and $P$. fortunei $(0.312)$ respectively. Pith to bark variations of specific gravity of growth rings for the three species are depicted in Figure 2. Accordingly, in S. macrophylla and K. senegalensi, specific gravity remained fairly uniform with little fluctuations over growth seasons, i.e. specific gravity remained more or less consistent from pith to bark. $P$. fortune on the other hand, showed a gradual increase in specific gravity from pith to bark. The increase in specific gravity was more prominent after the first 10 growth rings. This radial trend in specific gravity may be explained by the transition between juvenile wood and mature wood.

The fluctuations of mean ring width and mean specific gravity of each species with ring number from the pith are shown in Figure 3. Pearson's correlations tests were performed for each species to investigate the relationship between the variables ring width and whole ring specific gravity. The results are summarized in Table 2. Accordingly, no substantial pattern was observedin S. macrophylla suggesting that specific gravity is less affected by the growth rate. However, Pearson's correlations indicated a weak negativerelationship $(p=0.034)$ between ring width and specific gravity (Table 2). According to Figure 3, it appears that higher specific gravities are associated with narrower ring widths in $K$. senegalensis, and this is supported by a statistically significant positive correlation reported in 
Table 2. P. fortune also exhibited no clear variation pattern in specific gravity with growth rate as measured by ring width. The negative weak correlation between specific gravity and ring width was statistically non-significant at 0.05 level of significance (Table 2).

Table 2: Pearson's correlations between ring width and specific gravity for studies species

\begin{tabular}{lrrr}
\multicolumn{1}{c}{ Species } & Correlation $(\mathrm{r})$ & $p$ value & Significance $(\alpha=0.05)$ \\
\hline S. macrophylla & -0.186 & 0.034 & Significant \\
K. senegalensis & 0.266 & 0.008 & Significant \\
$P$. fortunei & -0.185 & 0.203 & Not Significant \\
\hline
\end{tabular}
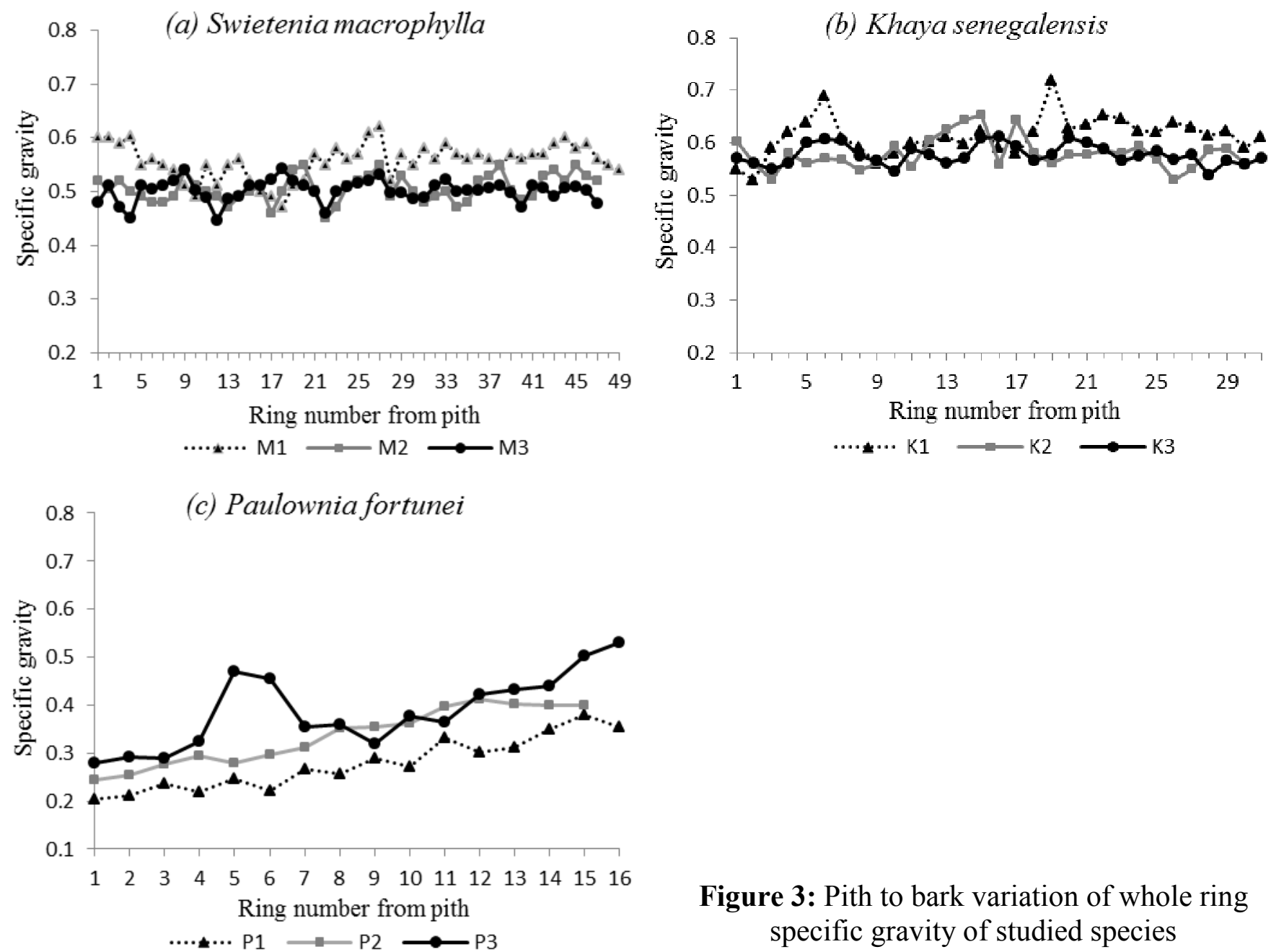

Figure 3: Pith to bark variation of whole ring specific gravity of studied species

Since Pearson's correlation test reported significance $(p<0.05)$ for both $S$. macrophylla and $K$. senegalensis, linear regression models were developed to explain the relationship between growth rate and specific gravity for the two species separately. However, linear regression analysis yielded poor coefficient of determination values $\left(R^{2}\right)$ for regression models developed for $S$. macrophylla $\left(R^{2}=0.08\right)$ and $K$. Senegalensis $(R=0.09)$ indicating the negligible effect of growth rate on whole ring specific gravity. 
(a) Swietenia macrophylla

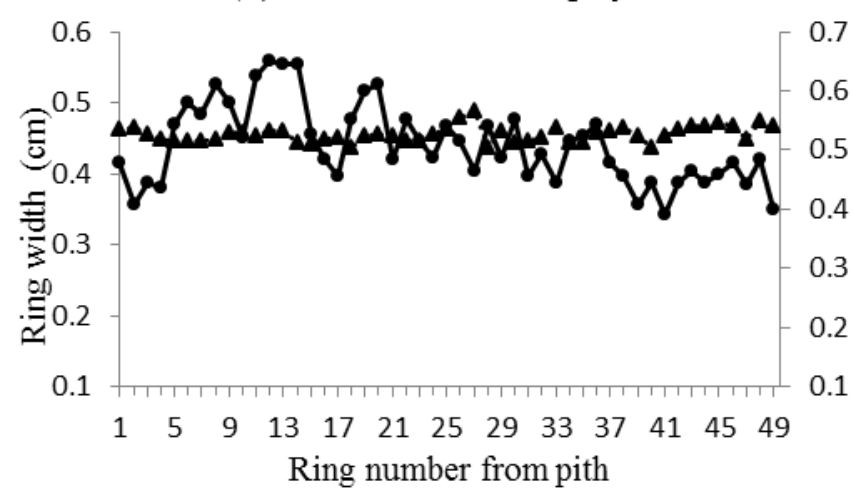

(c) Paulownia fortunei

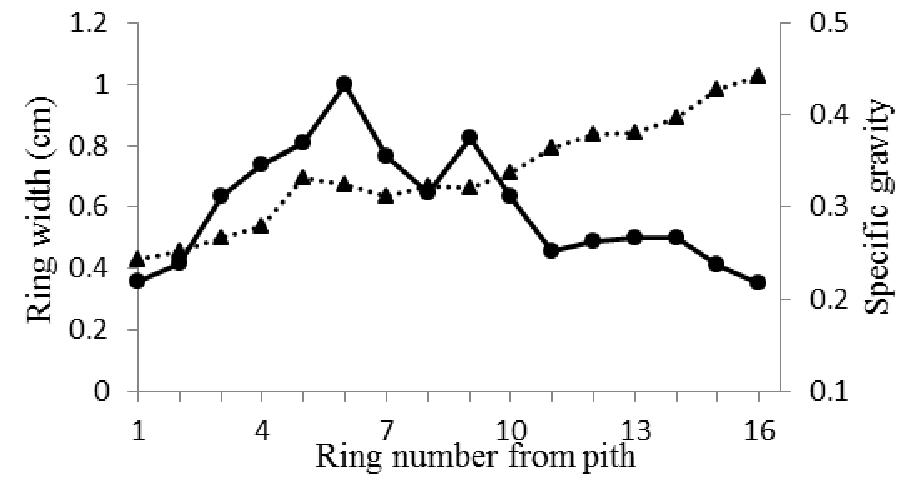

(b) Khaya senegalensis

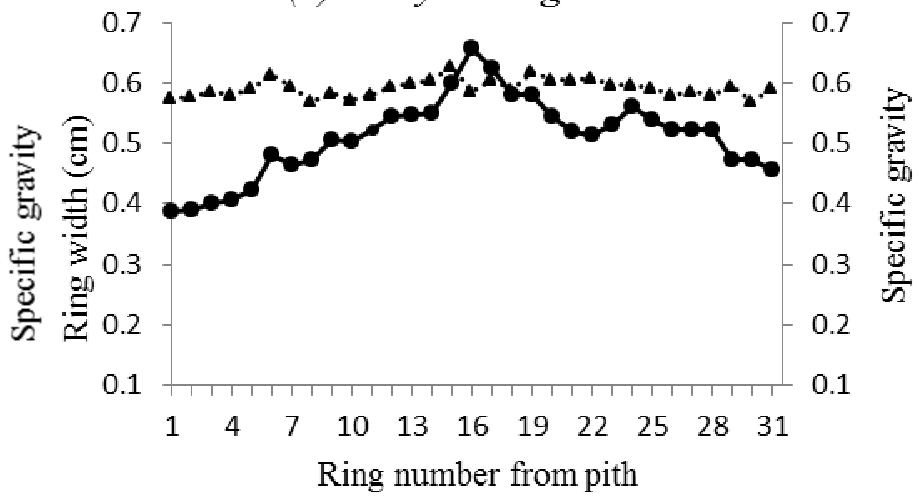

Ring width Specific gravity

Figure 4: Variation of mean specific gravity with growth rate as measured by ring width

\section{Discussion}

Changes in wood properties and woodstructure within the trunk from pith outwards are well documented for a wide range of species.An important research area is in distinguishing how wood characteristics are influenced by inherent trends from those that are also affected by growth rate (Amarasekera and Denne, 2002). A better understanding of these variations helps forester managers to better manipulate growth conditions to produce wood with a desired level of quality.

Previous researchon the effect of growth rate on wood properties of Sri Lankan hardwoods have been carried out using sampling methods based on percentage distances from the pith (Vivekanandan, 1978; Ruwanpathirana, 2002). The present study is the first attempt to investigate the variation of specific gravity of hardwoods based on sampling each ring from the pith. This approach may provide better insights to pith-to-bark variation patterns of specific gravity.

Ring width, measured using a travelling microscope, was used as an indicator of growth rate.Identification of growth rings in $S$. macrophylla and $K$. senegalensis was challenging. The number of growth rings observed for these species were well below their corresponding ages (maximum 49 rings for 79 year-old $S$. macrophylla and 35 rings for 49 year-old $K$. senegalensis). This scenario can be partially attributed to adverse growth conditions such as droughts that had occurred during the lifetime of trees causing cessation of the cambial activity (Larson, 1994). In addition, the presence of discontinuous/false rings was also common in the sample disks. However, for $P$. fortune, the number of growth rings observed was analogous to the tree age, i.e. 16 growth rings for 16year-old trees.

In both $S$. macrophylla and $K$. senegalensis, wider growth rings were observed for sheaths corresponding to aperiod of approximately 3 to 20 years in the tree life history. Thereafter, growth increments gradually declined for both species and remained more or less constant. Given the uniformity 
of specific gravity/wood quality from pith to bark, this may imply that both $S$. macrophylla and $K$. senegalensis can be managed for 20 to 30 year rotations. Ring width variation pattern in $P$. fortunei suggest that the species could be managed for rotations below 20 years.

The effect of growth rate on specific gravity of $S$. macrophylla has been discussed by several authors and the relationship can be considered as inconclusive. Briscoe et al. (1963) reported an increase in specific gravity of $S$. macrophylla with increased growth rates while Chudnoff and Geary (1973) found no significant relationship between tree size (representing the growth rate) and wood specific gravity. Analyzing ring characteristics of 30-year-old S. macrophylla, Lin et al. (2012) further concluded that it is unlikely for growth rates of plantation-grown mahogany trees to have a significant impact on wood specific gravity. From the present work, it was observed that specific gravity shows a poor correlation with growth rate measured by ring width. Hence it is unlikely that wood specific gravity of these species can be changed by influencing growth rate.

In most trees, the first 10 growth rings, or the wood formed during the first 10 years of growth, are considered to be juvenile wood (Sanwo, 1987) and wood properties tend to vary greatly in this zone (Amarasekera and Denne, 2002). In this study, the specific gravity remained more or less uniform from pith to bark regardless of the fluctuation of ring width in K. senegalensis while S. macrophylla exhibited a slight increase from pith to bark. The increasing radial trend in specific gravity was more prominent in $P$. fortunei. This may suggest that the cambium in $P$. fortunieitends to produce denser wood as the cambium matures. Lin et al. (2012) also observed a gradual increase in specific gravity from pith outwards in plantation grown $S$. macrophylla. In $K$. senegalensis, it seems that specific gravity does not considerably change between juvenile wood and mature wood zones, and the cambium produces uniform wood throughout the year. These results can be used to help determine optimal rotation ages for the species researched in this study.

\section{Conclusion}

No substantial and definite relationship appears to exist between whole ring specific gravity and ring width representing the growth rate in $S$. macrophylla, $K$. senegalensis and $P$. fortuniei. Hence, results suggest that growth rate does not significantly affect specific gravity or wood quality of these species.

\section{References}

Amarasekera, H. 1996. Alternative timber species; A review of their properties and uses,. In H. S. Amarasekera, \& S. G. Banyard (Ed.), Forestry for Development: Proceedings of the Annual Forestry Symposium 1995, December (pp. 76-88). Sri Lanka: Department of Forestry and Environmental Sciences.

Amarasekera, H., and Denne, M. 2002. Effects of crown size on wood characteristics of Corsican pine in relation to definitions of juvenile wood, crown formed wood and core wood. Forestry, 75(1), 51-61.

Bao, F., Jiang, Z. H., Jiang, X. M., Lu, X. X., Luo, X. Q., and Zhang, S. Y. 2001. Differences in wood properties between juvenile wood and mature wood in 10 species grown in China. Wood Science and Technology, 35(4), 363-375.

Bhat, K M and Bhat, K. V. 1983.Wood properties of 1-year-old Eucalytus tereticornis, IUFRO Conference Division 5 Madison, Wisconsin, 1 p (Summary).

Bhat, K M. 1985. Properties of selected lesser-known tropical hardwoods.Journal of the Indian Academy of Wood Science, 16(1), 26-35.

Briscoe, C B, Harris, J. B, and Wyckoff, F. 1963, Variation of specific gravity in plantation-grown trees of big-leaf mahogany.Caribbean Forestry, 24, 67- 74. 
CBSL, 2004.Annual Report of the monetary board of the Hon. Minister of Finance for the year 2004.Central Bank of Sri Lanka, Colombo 01, Sri Lanka.

Chudnoff, M and Geary, T F. 1972. On the heritability of wood density in Swietenia macrophylla, Turriablba 23, 359-36.

Forestry Sector Master Plan,1995.Forest sector development division, Ministry of Agriculture, Lands and Forestry.511 pp.

Haslett, A.N. and Young,G.D. 1990.Plantation grown tropical timbers 1.Wood property and processing evaluation procedures to improve usage.Journal of Tropical Forest Science, 3(2):131-139.

Haslett, A.N., Young, G.D, and Britton, R.A.J. 1991. Plantation grown tropical timbers 2.Properties, processing and uses.Journal of Tropical Forest Science, 3(3): 229-237.

Herman, M., Dutilleul, P., \& Avella-Shaw, T. (1998). Growth Rate Effects on Temporal Trajectories of Ring Width, Wood Density, and Mean Tracheid Length in Norway Spruce (Picea Abies (L.) Karst.). Wood and Fiber Science, 30(1), 6-17.

Hua Lei, H., Gartner, B., and Milota, R. 1997. Effect of growth rate on the anatomy, specific gravity, and bending properties of wood from 7-year-old red alder (Alnus rubra). Canadian Journal of Forest Research, 27, 80-85.

Jørgensen, I., and Vivekanandan, K. 2003. Private forestry based on Paulownia in Sri Lanka: an appraisal of the outgrower scheme presented by Paulownia Plantations LTD. Norway: Noragric Agricultural University of Norway.

Larson, P R (1972), Evaluating the quality of fast-grown coniferous wood, Proceedings West For Conf. Seattle, Washington, 1- 7.

Lin, C., Chung, C., Cho, C.,and Yang, T. 2012. Tree ring characteristics of 30-year old Swietenia macrophylla plantation trees. Wood and Fiber Science, 44 (2), 1-12.

Mac Donald, R.G.and Franklin, N.J. 1969.Pulp and paper manufacturer, Vol.1.The pulping of wood $2^{\text {nd }}$ ed. McGraw-Hill, NY.

Ministry of Environment and Natural Resources Sri Lanka, 2002.National report of Sri Lanka to the World Summit on Sustainable Development.Ministry of Environment and Natural Resources, Sri Lanka.35-36.

Nock, C., Geihofer, D., Grabner, M., Baker, P., Bunyavejchewin, S., and Hietz, P. 2009. Wood density and its radial variation in six canopy tree species differing in shade-tolerance in western Thailand. Annals of Botany, 104(2), 297-306.

Pearson, R.G. andGilmore, R.C. 1980. Effect of fast growth rate on the mechanical properties of loblolly pine. Forest Products Journal, 30(5):47-54.

Perera, P., Vlosky, R., Amarasekera, H., and De Silva, N. 2006. Forest Certification in Sri Lanka. Forest Products Journal, 56(11/12), 5-11.

Pérez, D. \&Kanninen, M. 2005.Effect of thinning on stem form and wood characteristics of teak (Tectonagrandis) in a humid tropical site in Costa Rica. Silva Fennica 39(2): 217-225.

Ruwanpathirana, N. D. 2002.Variation of some wood properties of Eucalyptus grandis and Pinus caribaea in different site classes, PhD Thesis. Department of Botany, University of Ruhuna, Sri Lanka, 30-133.

Sanvo, S. 1987. The charactoristics of the crown-formed and stem-formed wood in plantation grown teak (Tectona grandis L.f) in Nigeria. Journal of institute of Wood Science, 11(2), 85-88.

Schmidtling, R.C. and Amburgey, T.L. 1977. Growth and wood quality of slash pines after early cultivation and fertilization.Wood Science, 9(4): 154-159.

Simatupang, M., Yamamoto, K., HingHong, C., and Matsumoto, K. 2000. Properties of teak wood (Tectona grandis L.f) and mahogany (Swietenia macrophylla King) from manmade forest and influence on utilization. JIRCAS.

Smith, D. 1954. Maximum moisture content method for determining specific gravity of small wood samples. USA: USDA Forest Service Forest Products Laboratory. 
Woodcock, D., \& Shier, A. D. (2002). Wood specific gravity and its radial variations: the many ways to make a tree. Trees - Structure and Function, 16(6), 437-443.

Zhang, S.Y. 1995. Effect of growth rate on wood specific gravity and selected mechanical properties in individual species from distinct wood categories. Wood science and Technology, 29(6); 451-465.

Zobel, B. J., and van Buijtenen, J.P. 1989.Wood variation its causes and control, Springer-Verlag, Berlin, Germany, 354-358pp. 